\title{
FORECASTING NEGATIVE CONSEQUENCES OF MANURE HANDLING PRACTICES: CASE OF OUTER AIR
}

\author{
Ekaterina Shalavina, Alexander Briukhanov, Eduard Vasilev \\ Federal Scientific Agroengineering Centre VIM, Russia \\ shalavinaev@mail.ru, sznii@yandex.ru
}

\begin{abstract}
Agricultural production is an economic activity that has a significant impact on the atmosphere. The distributed pollution sources and a wide variety of agricultural practices and facilities present challenges to an accurate inventory of harmful emissions from agriculture. The ongoing farming capacity building and construction of new livestock and poultry complexes make it a very important issue to address. According to previous studies, the main emission source here is animal manure handling. The study aimed to establish a forecast model of the adverse effect of manure handling technologies on the outer air. The logico-linguistic modelling was applied for this purpose (Spesivtsev-Drozdov approach). It allowed formalising the expert judgements into the analytical expressions of the polynomial type. The study identified four relevant dominant factors: $X 1$ - manure processing technology; $X 2$ - gas emission treatment technology; $X 3$ - agro-technical and agro-ecological requirements; and $X 4$ - digitalisation. The factor analysis revealed Factor $X 2$ with a weight coefficient of 0.5 and Factor $X 1$ with a weight coefficient of 0.3 to be the most significant ones. The resulting polynomial expressions forming the model were checked for adequacy by finding the correlation of expert and calculated estimates. The correlation coefficients were $98.65 \%$ and $96.6 \%$, respectively, indicating a high agreement degree. In practice, the designed model can be an effective tool in decision-making related to choosing the relevant abatement measures and the upgrading options of agricultural enterprises based on the forecasts of their environmental impact depending on different technological and management solutions.
\end{abstract}

Keywords: emissions, manure, technology, modelling, ecology.

\section{Introduction}

The agricultural industry is an economic activity with a significant impact on atmospheric air [14]. The main aerial pollutants from agricultural enterprises are ammonia $\left(\mathrm{NH}_{3}\right)$, nitrogen oxide and dioxide, nitrous oxide, hydrogen sulfide, methane, methanol, carbon dioxide, hydroxybenzene, ethyl formate, propanal, hexanoic acid, dimethyl sulfide, methanethiol, methylamine, and fur dust [5].

The manure and manure-based organic fertilisers are the main ammonia emission source in farming. On the one hand, $\mathrm{NH}_{3}$ is the basis for amino acids, proteins and enzymes. On the other hand, high ammonia concentrations generate airborne solid particles, which can compromise animal and human health. [6-7].

The exhaust gases of agricultural machines are the source of nitrogen oxides and dioxides $\left(\mathrm{NO}_{\mathrm{X}}\right)$. In general, $\mathrm{NO}_{\mathrm{X}}$ is a vital component in terms of human physiology. At the same time, nitrogen oxides and dioxides are the main air pollutants that cause heart and respiratory diseases [8-9].

Agriculture is also a source of nitrous oxide $\left(\mathrm{N}_{2} \mathrm{O}\right)$, a greenhouse gas contributing to stratospheric ozone depletion. Competent emission management of air pollutants will allow forecasting the environmental impact of intensive machine-based farming technologies [10-11].

The main challenge in this context is an integrated assessment of all the technologies and facilities involved in manure handling. Currently, this is a very important issue to address because of the ongoing farming capacity building and construction of new livestock and poultry complexes.

The study aimed to establish a forecast model of the negative application consequences of manure handling technologies for the outer air.

This model will allow for generating scenarios of such consequences depending on different technological and management solutions, including digitalisation. It means the introduction of a framework of interacting technical means, software, information and control systems and networks, and organisational and economic links. Making use of the digital activity model, this approach contributes to the sharp increase in the general efficiency and sustainability of an agricultural enterprise.

\section{Materials and methods}

The logico-linguistic modelling (Spesivtsev-Drozdov approach) was applied to establish a target model. The basis of the approach is formalising the expert judgements in logical-linguistic model- 
building for fuzzy multidimensional systems. This is a reasonably well-tested method, which was used for solving agro-ecological problems among others [12-14].

The advantage of logical-linguistic model-building is the use of the professional language of even one expert by introducing linguistic variables that adequately reflect a rough verbal description of objects and phenomena even in cases when a deterministic description is missing or generally impossible $[15 ; 16]$. The aggregate interaction of criteria is formalised by forming an evaluative opposition-based scale of criteria. Only the scale ends are marked. The centre corresponds to the neutral value between the scale ends. The intermediate values are marked by further dividing the scale. This way the expert's conceptual assessments are ranked.

In our study, this approach involved the following actions:

1. defining the $x$-space of the phenomenon under consideration. In our case, it included the most significant factors affecting the air emissions when manure was processed into organic fertiliser;

2. defining the ranges of accepted values for each factor. In our case, the interval $(-1 ;+1)$ was adopted to estimate the factors affecting the outer air, with (-1) corresponding to the factor with the biggest impact and (+1) - with the smallest impact;

3. selecting a target function and deriving an equation, which would show its dependence on the factor variables;

4. preparing a matrix for expert survey with all significant factors and sub-factors affecting the outer air;

5. conducting an expert inquiry, that is, an expert was given a certain set of values of input linguistic variables, which he used in his relevant assessment;

6. analysing the expert estimates by regression analysis method;

7. obtaining the numerical values of the coefficients in the resulting model;

8. verifying the resulting model by the determination coefficient;

9. $\quad$ estimating the model error by $F$-test.

Out of the main aerial pollutants from agricultural enterprises the methane $\mathrm{CH}_{4}$ ammonia $\mathrm{NH}_{3}$ and nitrous oxide, $\mathrm{N}_{2} \mathrm{O}$ were studied in detail.

The above method was tested on the initial data from livestock and poultry farms in Leningrad Region. Three researchers with many years' experience in measuring and calculating pollutant emissions from livestock and poultry farms were invited as experts. The regression analysis was performed using Scilab 6.1.0 computer programme.

\section{Results and discussion}

Following the chosen method of logico-linguistic modelling, the target indicator $(Y)$ in the study was the level of adverse effect on the outer air of processing one ton of manure into organic fertiliser. Four factors were identified as having a highly relevant effect:

- $X 1$ - applied manure processing technology into organic fertiliser;

- $X 2$ - applied gas emission treatment technology;

- $X 3$ - compliance with agro-technical and agro-ecological requirements;

- $X 4$ - use of digital technologies in technological processes.

Factor $X 1$ was considered for manure processing into solid or liquid organic fertilisers. For producing the solid organic fertiliser, factor $X 1$ implied the application of one of the following eight technologies:

- $X 1.1$ - long-term storing (maturing);

- $X 1.2$ - passive composting on a concrete pad with covering;

- $X 1.3$ - passive composting on a concrete pad without covering;

- $X 1.4$ - active composting on a concrete pad with covering;

- $X 1.5$ - active composting on a concrete pad without covering;

- $X 1.6$ - bio-fermentation in a drum fermenter;

- $X 1.7$ - bio-fermentation in a chamber fermenter;

- $X 1.8$ - oven drying. 
The degree of pollutant emission into the outer air varied considerably with the selected processing technology (Fig. 1).

For producing the liquid organic fertiliser, factor $X 1$ implied the application of one of the following eight technologies:

- $X 1.1$ - long-term storing (maturing) in the open-type manure storage facility - without a natural crust;

- $X 1.2$ - long-term storing in the uncovered manure storage facility with a natural crust;

- $X 1.3$ - long-term storing in the open-type manure storage facility with covering by natural material (straw, wood shavings, etc.);

- $X 1.4$ - long-term storing in the open-type manure storage facility with floating plastic foam balls;

- $X 1.5$ - long-term storing in the open-type manure storage facility with a rigid cover;

- $X 1.6$ - long-term storing in the manure storage facility with a floating plastic cover;

- $X 1.7$ - anaerobic fermentation with resulting biogas;

- $X 1.8$ - multi-stage aerobic processing.

The degree of pollutant emission into the outer air varied considerably with the selected processing technology (Fig. 1).

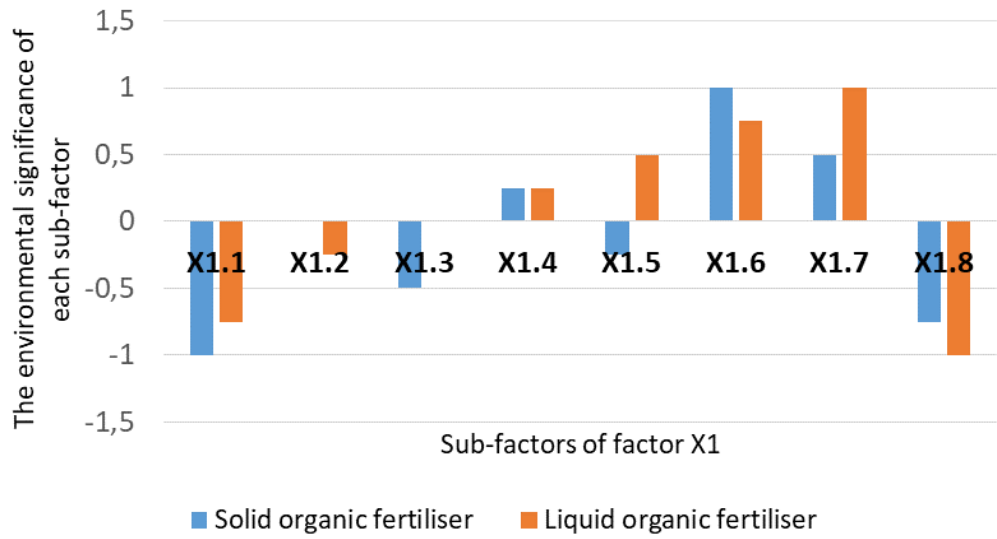

Fig. 1. Sub-factors of factor $\boldsymbol{X} \mathbf{1}$ - manure processing technologies into organic fertilisers

The most ambient air friendly sub-factor in the solid organic fertiliser production was $X 1.6$ - biofermentation in a drum fermenter. The sub-factor X1.1 - long-term storing (maturing), featured the biggest air pollutant emission [17-18]. The most ambient air friendly sub-factor in the liquid organic fertiliser production was $X 1.7$ - anaerobic fermentation with resulting biogas. The sub-factor $X 1.8-$ multi-stage aerobic processing, demonstrated the biggest air pollutant emission [19-20]. Manure handling practices generate the emissions of $\mathrm{CH}_{4}$ and $\mathrm{NH}_{3}$ during manure processing into organic fertiliser [21].

Factor $X 2$ implied the selection of one of the following four gas emission treatment technologies when producing solid and liquid organic fertilisers with different pollutant emission degree (Fig. 2):

- $X 2.1$ - no gas emission treatment system in place;

- $X 2.2$ - gas emission treatment by physical filtration techniques;

- $X 2.3$ - gas emission treatment by chemical filtration techniques;

- $X 2.4$ - gas emission treatment by biological filters with organic components.

In our case, the most ambient air friendly was the sub-factor $X 2.3$ - gas emission treatment using chemical filtration techniques. The sub-factor $X 2.1$ - when there was no gas emission treatment system in place demonstrated the biggest air pollutant emission.

The weight coefficients of sub-factors of factors $X 1$ and $X 2$ were determined for particular technological options from the list. Moreover, only one sub-factor of each factor could be in place at a time. 
Several sub-factors of below factor $X 3$ can be used at a time. Each sub-factor of factor $X 3$ can take a positive value, if this management method is applied, or a negative value, if this management method is not applied.

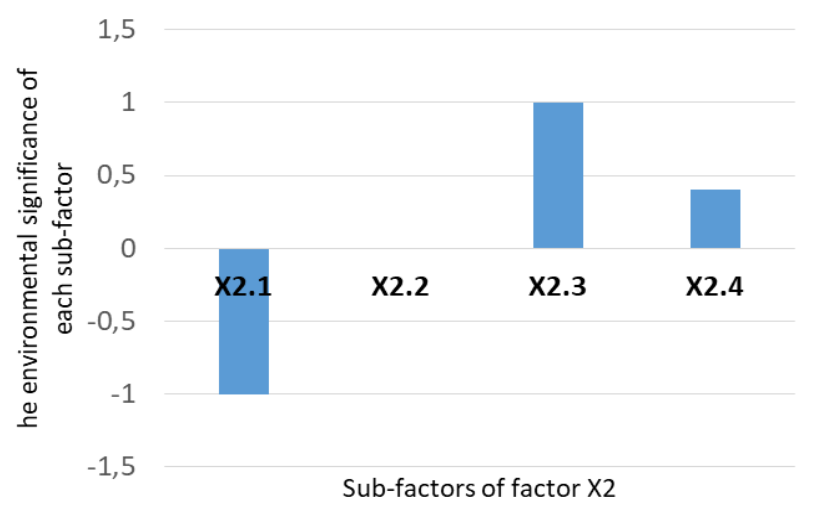
Fig. 2. Sub-factors of factor $X 2$ - technologies for gas emission treatment when
producing solid and liquid organic fertilisers

Factor $X 3$ reflected compliance with agro-technical and agro-ecological requirements:

- X3.1 - observance of regulations for technological processes;

- X3.2 - observance of time frames of technological processes;

- $X 3.3$ - work culture (human factor).

The environmental significance of sub-factors of factor $X 3$ is shown in Equation 1:

$$
X 3=-0.03125+0.5625 \cdot X 3.1 .+0.25 \cdot X 3.2 .+0.2188 \cdot X 3.3
$$

The adequacy of Equation 1 was proved by Fisher's test and the determination coefficient $\left(R^{2}\right)$. It was found that $98.65 \%$ of the total variability in $X 3$ is due to the changes in sub-factors $X 3.1$. to $X 3.3$ that makes the equation statistically significant.

In our case, $X 3.1$ - compliance with regulations of technological processes, was the most significant sub-factor in terms of the impact on the outer air. The least significant sub-factor was $X 3.3$ - work culture (human factor) [22].

Factor $X 4$ reflected application of digital technologies in the technological processes:

- $X 4.1$ - no digital technologies applied;

- $X 4.2$ - availability of automation tools for technological process control: the operator makes decisions and undertakes actions;

- X4.3 - integrated automation - automatic control and adjustment of technological process regulations.

In our case, $X 4.3$ - integrated automation, was the most significant sub-factor in terms of the impact on ambient air. The least significant sub-factor was $X 4.1$ - no digital technologies applied.

The above set of factors and sub-factors resulted from a comprehensive approach to forecasting air pollutant emissions. Factors $X 1$ to $X 2$ characterised the applied machine-based technologies, factors $X 3$ to $X 4$ - the applied management decisions. Factor $X 4$ also characterised the efficiency of the process control and allowed for a more accurate estimation of the impact of management decisions made.

The resulting factor space was used to create a logical-linguistic model. The scales were built for the target function $Y$ and each sub-factor, allowing to correlate the linguistic expert estimates and logical values $(-1 ;+1)$. The scales had the following linguistic estimates: $\mathrm{L}-$ low level of pollutant input to the outer air; BA - input level below average; A - average input level; AA - input level above average; $\mathrm{H}$ - high level of pollutant input (Fig. 3).

Later more detailed linguistic estimates were used, for example, BA-A - the pollution input level between BA (below average) and A (average), BAA-A - the pollution input level between BA-A (below average and average) and $\mathrm{A}$ (average), etc. 


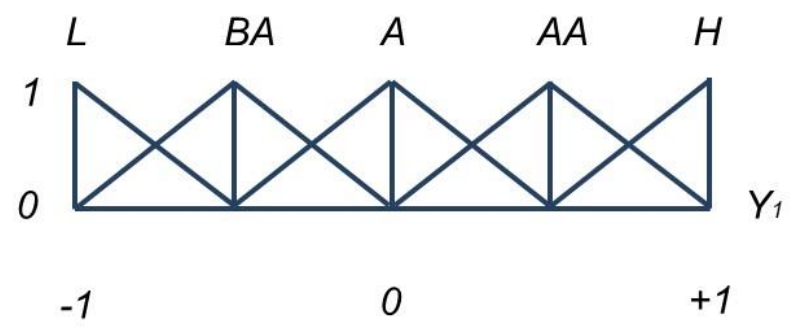

Fig. 3. Logico-linguistical scale following Spesivtsev-Drozdov approach

After the environmental significance each sub-factor was determined, an expert-survey matrix was constructed for the general target function $Y$, with the experts' estimates of the negative impact depending on various combinations of the values of previously selected sub-factors. The complete matrix had 16 rows of the factor value combinations. The filled-in matrix is presented in Table 1.

Table 1

Expert-survey matrix with experts' estimates and calculated values by the model

\begin{tabular}{|c|c|c|c|c|c|c|c|}
\hline Estimate & $\boldsymbol{X} 1$ & $\boldsymbol{X} 2$ & $\boldsymbol{X} 3$ & $\boldsymbol{X} 4$ & $\boldsymbol{Y} 1$ & $\boldsymbol{Y} 2$ & $\boldsymbol{Y} 3$ \\
\hline 1 & 1 & 1 & 1 & 1 & H & 1.000 & 1.020 \\
\hline 2 & 1 & 1 & 1 & -1 & AAH-H & 0.875 & 0.850 \\
\hline 3 & 1 & 1 & -1 & 1 & AA-H & 0.750 & 0.850 \\
\hline 4 & 1 & 1 & -1 & -1 & AA-AAH & 0.625 & 0.670 \\
\hline 5 & 1 & -1 & 1 & 1 & BA-BA-A & -0.375 & 0.009 \\
\hline 6 & 1 & -1 & 1 & -1 & BA-A & -0.250 & -0.160 \\
\hline 7 & 1 & -1 & -1 & 1 & BA-A-A & -0.125 & -0.160 \\
\hline 8 & 1 & -1 & -1 & -1 & BA-BA-A & -0.375 & -0.330 \\
\hline 9 & -1 & 1 & 1 & 1 & AA & 0.500 & 0.410 \\
\hline 10 & -1 & 1 & 1 & -1 & A & 0.000 & 0.240 \\
\hline 11 & -1 & 1 & -1 & 1 & A-A-AA & 0.125 & 0.240 \\
\hline 12 & -1 & 1 & -1 & -1 & BA-A-A & -0.125 & 0.070 \\
\hline 13 & -1 & -1 & 1 & 1 & LBA-BA & -0.625 & -0.600 \\
\hline 14 & -1 & -1 & 1 & -1 & L-BA & -0.75 & -0.770 \\
\hline 15 & -1 & -1 & -1 & 1 & L-LBA & -0.875 & -0.770 \\
\hline 16 & -1 & -1 & -1 & -1 & L & -1.000 & -0.940 \\
\hline
\end{tabular}

Columns $X 1-X 4$ are filled in with logical values $(-1 ;+1)$, corresponding to the minimum and maximum values of the factor variables following the Spesivtsev-Drozdov approach. Column $Y 1$ shows the experts' linguistic estimates, which were converted into the numerical form (Y2) according to the relevant scale and calculated by the model $(Y 3)$.

Further, after regression analysis for column $Y 2$, a polynomial expression was obtained that reflected the effect of selected factors on the level of negative impact on the outer air (Equation 2):

$$
Y=-0.03906+0.3047 \cdot X 1+0.5078 \cdot X 2+0.08594 \cdot X 3+0.08594 \cdot X 4
$$

As a result, the most significant factors in terms of the impact on the outer air were $X 1$ - applied manure processing technology into organic fertiliser, and $X 2$ - applied gas emission treatment technology. The least significant factors were $X 3$-compliance with agro-technical and agro-ecological requirements and $X 4$ - use of digital technologies in technological processes.

The adequacy of Equation 2 was proved by the determination coefficient $\left(R^{2}\right)$ and Fisher's test. It was found that $96.6 \%$ of the total variability in $Y$ is due to the changes in the factors $X 1$ ещ $X 4$ that makes the equation statistically significant.

Comparison of the study results with other investigations showed that proper gas emission cleaning technologies and the grounded technological solutions for manure processing into organic fertiliser contribute to the reduction of gas emissions from a livestock complex to the greatest extent $[23 ; 24]$. 


\section{Conclusions}

1. A mathematical model consisting of two equations for forecasting the negative impact of manure handling technologies on the outer air was designed by the logico-linguistic method of formalising the expert knowledge concerning the fuzzy multidimensional systems.

2. The main factors affecting the outer air in this activity type were $X 1$ - manure processing technologies; $X 2$ - gas emissions treatment technologies; $X 3$ - agro-technical and agro-ecological requirements; and $X 4$ - digitalisation.

3. According to the factor analysis results, the most significant factors in terms of the impact on the outer air were factor $X 2$ - the gas emission treatment technology with a weight coefficient of 0.5 , and factor $X 1$ - the manure processing technology with a weight coefficient of 0.3 .

4. The resulting polynomial expressions were checked for adequacy by finding the correlation of expert and calculated estimates. The correlation coefficients were $98.65 \%$ and $96.6 \%$, respectively, indicating a high agreement degree.

5. In practice, the designed model can be an effective tool in assessing the current negative impact of agricultural enterprises on the outer air; in introducing the abatement measures based on the most significant factors and sub-factors identified in each case; in choosing the upgrading options of agricultural enterprises by the forecasts of their environmental impact depending on different technological and management solutions.

\section{References}

[1] Frolova O., Priekulis J., Berzina L., Aboltins A. Trend of ammonia emissions from livestock sector in Latvia. Proceedings of the 19th International Scientific Conference "Engineering for rural development". 2020. Vol.19. pp. 598-602.

[2] Zebartha B.J., Paul J.W., Van Kleeck R. The effect of nitrogen management in agricultural production on water and air quality: evaluation on a regional scale. Agriculture, Ecosystems \& Environment. 1999. Vol.72, Issue 1, pp 35-52

[3] Mieldazys R., Jotautiene E., Jasinskas A., Aboltins A. Estimation of the emissions from point of view of litter manure management in Lithuanian agriculture. Proceedings of the 19th International Scientific Conference "Engineering for rural development". 2020. Vol.19. pp. 300-305.

[4] Aboltins A., Melece L., Priekulis J. Model for ammonia emissions' assessment and comparison of various dairy cattle farming systems and technologies. Agronomy Research, 2019, 17 (2), pp. 322332.

[5] Рекомендации по расчету выбросов загрязняющих веществ в атмосферный воздух от объектов животноводства и птицеводства (Recommendations to calculate atmospheric pollutant emissions from the objects of animal and poultry production). AO «НИИ Атмосфера»: JSC «SRI Atmosphere». Saint Petersburg, 2015. 40 p.

[6] Bittman S., Dedina M., Howard C.M., Oenema O., Sutton M.A., (eds). Options for Ammonia Mitigation: guidance from the UNECE Task Force on Reactive Nitrogen. Edinburgh: NERC/Centre for Ecology \& Hydrology. 2014. 83 p. [online] [02.02.2021]. Available at: http://nora.nerc.ac.uk/id/eprint/510206/1/N510206CR.pdf

[7] Sutton, M.A. et al. Toward a climate-dependent paradigm of ammonia emission \& deposition. Phil. Trans. Roy. Soc. (Ser. B). 2013. Vol. 368, Issue 1621. http://dx.doi.org/10.1098/rstb.2013.0166

[8] Alcamo J., Leonard S.A., Ravishankara A.R., Sutton M.A. (eds.). Drawing Down $\mathrm{N}_{2} \mathrm{O}$ to Protect Climate and the Ozone Layer: A UNEP Synthesis Report. 2013. Nairobi. [online] [02.02.2021]. Available at: http://wedocs.unep.org/handle/20.500.11822/8489

[9] FRONTIERS 2018/19: Emerging Issues of Environmental Concern. United Nations Environment Programme. Nairobi. 2019. 80 p. [online] [02.02.2021]. Available at http://purl.unep.org/sdg/SDGIO_00000037.

[10] Lelieveld J., Evans J.S., Fnais M., Giannadaki D., Pozzer A. The contribution of outdoor air pollution sources to premature mortality on a global scale. Nature. 2015. Vol. 525, pp. 367-371. DOI: 10.1038/nature15371

[11] Brunekreef, B. et al. Reducing the health effect of particles from agriculture. Lancet Respiratory Medicine. 2015. 3(11), pp. 831-832. DOI: 10.1016/S2213-2600(15)00413-0 
[12] Спесивцев А.В. Формализация и использование явных и неявных экспертных знаний для оценивания состояния сложных объектов. Диссертация на соискание ученой степени доктора технических наук. (Formalization and use of explicit and implicit expert knowledge for assessing the state of complex objects. DSc (Engineering) Diss.). Saint Petersburg. SPIIRAS. 2019. 357 p. (In Russian)

[13] Дроздов А.В., Спесивцев А.В. Формализация экспертной информации при логиколингвистическом описании сложных систем (Formalization of expert information in the logicallinguistic description of complex systems). Technical cybernetics: Техническая кибернетика. 1994, No. 2. pp. 89-96. (In Russian)

[14] Briukhanov, A., Trifanov A., Spesivtsev A., Subbotin I. Logical-linguistic modeling in addressing agro-environmental challenges. Proceedings of XIX IEEE International Conference on Soft Computing and Measurements (SCM). Saint Petersburg. 2016. pp. 164-166.

DOI: 10.1109/SCM.2016.7519716.

[15] Моисеев Н.Н. Математические задачи системного анализа (Mathematical problems of system analysis). Moscow: Nauka Publ: М.: Наука 1981. 328 p. (In Russian)

[16] Мышко В.В., Кравцов А.Н., Копкин Е.В., Чикуров В.А. Теоретические основы и методы оптимизации анализа технического состояния сложных систем/Монография (Fundamentls and optimisation methods of the analysis of the technical state of complex systems. Monograph). Saint Petersburg: Mozhaisky Academy, 2013. 303 p. (In Russian)

[17] Брюханов А.Ю. Методы проектирования и критерии оценки технологий утилизации навоза, помета, обеспечивающие экологическую безопасность. Диссертация на соискание ученой степени доктора технических наук. (Designing methods and assessment criteria of technologies for utilisation of farm animal/poultry manure ensuring the environmental safety. DSc (Engineering) Diss.) Saint Petersburg: SPbGAU. 2017. 440. (In Russian)

[18] Ciganek M., Neca J. Chemical characterization of volatile organic compounds on animal farms. Veterinarni Medicina. 2008. Vol. 53 (12). pp. 641-651.

[19] Шалавина Е.В., Васильев Э.В. Изменение содержания азота и фосфора в жидкой фракции свиного навоза при биологической очистке (Change in nitrogen and phosphorus content during biological treatment of liquid fraction of pig manure). Technologies, machines and equipment for mechanised crop and livestock production: Технологии и технические средства механизированного производства продукции растениеводства и животноводства. 2014. №. 85. pp. 146-150 (In Russian)

[20] Лачуга Ю.Ф., Измайлов А.Ю., Лобачевский Я.П., Шогенов Ю.Х. Развитие интенсивных машинных технологий, роботизированной техники, эффективного энергообеспечения и цифровых систем в агропромышленном комплексе (Development of intensive machine technologies, robotic technology, efficient energy supply and digital systems in the agribusiness). Machinery and Equipment for Rural Area: Техника и оборудование для села. 2019. №. 6 (264). pp. 2-9 (In Russian)

[21] Sindhöj E., Kaasik, A., Kuligowski, K. et al. Manure Properties on Case-Study Farms in the Baltic Sea Region. Report 417. Agriculture \& Industry, JTI. Uppsala, Sweden. 2013. 77p.

[22] Шалавина Е.В., Васильев Э.В. Алгоритм принятия решений при выборе машинных технологий биоконверсии отходов животноводства (Decision-making algorithm when choosing machine technologies for bioconversion of animal waste). Agricultural Bulletin of Stavropol Region: Вестник АПК Ставрополья. 2015. No. 1 (17). pp. 366-370 (In Russian)

[23] Haenel H-D., Rösemann C., Dämmgen U. et al. Calculations of gaseous and particulate emissions from German agriculture 1990 - 2016. Report on methods and data (RMD). Braunschweig: Johann Heinrich von Thünen-Institut, 2018. 424 p. [online] [02.03.2021] Available at: https://literatur.thuenen.de/digbib_extern/dn053407.pdf

[24] CEIP Centre on Emission Inventories and Projections. Officially reported emission data. 2019. [online] [02.03.2021] Available at: https://www.ceip.at/ms/ceip_home1/ceip_home/webdab_emepdatabase/reported_emissiondata/ 